Citation: Girişken, A., \& Çalımlığlu Doğan, E., Understanding Working Mothers from the Perspective of Organizational Commitment in Turkey, BMIJ, (2020), 8(4): 1015-1032, doi: http://dx.doi.org/10.15295/bmij.v8i4.1584

\title{
UNDERSTANDING WORKING MOTHERS FROM THE PERSPECTIVE OF ORGANIZATIONAL COMMITMENT IN TURKEY
}

\author{
Arzu GİRIŞKEN 1 \\ Received Date (Başvuru Tarihi): \\ $5 / 08 / 2020$ \\ Elif ÇALIMLIOĞLU DOĞAN 2 \\ Accepted Date (Kabul Tarihi): \\ $5 / 11 / 2020$ \\ Published Date (Yayın Tarihi): \\ $10 / 12 / 2020$
}

In the article, the first author is in the role of the Corresponding Author.

ABSTRACT

Keywords:

Organization,

Organizational Commitment,

Working Women,

Working Mothers

JEL Codes:

M00, M14

Today, especially in developing countries, the majority of working mothers in institutions' organizational structures, feel disturbed and excluded. This article aims to examine the relationship between challenges faced by working mothers in Turkey and their view of organizational commitment with a scientific approach. This study also aims to discuss the gender and maternal identity of working women by considering the difficulties they have in their both business and family lives. The survey designed for this article was applied to 105 working mothers living in Istanbul, and 82 of them completed it. In this online quantitative study, the living standards of working mothers, the capacity of the institution to support them, and the relationship between work-family life and organizational commitment were investigated. As a result of this study, it was found that there is a significant relationship between corporate commitment and life satisfaction, identities (work and family, etc.), job satisfaction, and organizational support for working mothers, and a significant negative relationship was found between corporate commitment and work-family life conflict.

\section{TÜRKIYYE'DE ÇALIŞAN ANNELERİ ÖRGÜTSEL BAĞLILIK PERSPEKTIFINDEN BAKARAK ANLAMAK}

$\ddot{O Z Z}$

Anahtar Kelimeler:

Kurum,

Örgütsel Bağlllık,

Çalı̧an Kadınlar,

Çalışan Anneler

JEL Kodlari:

M00, M14
Günümüzde, özellikle gelişmekte olan ülkelerde, kurumlarn örgütsel yapılarında çalışan annelerin önemli bir bölümü rahatsız ve dışlanmıs hissetmektedir. Bu makalede amaçlanan; Türkiye'de çalışan annelerin yaşadıklar zorluklarla örgütsel bağlilı̆̆a bakışlarının arasında bir ilişki olup olmadığını bilimsel bir yaklaşımla incelemektir. Bu araştırmada ayrıca çocuk sahibi çalışan kadınların cinsiyet ve sahip olduklarn annelik kimliklerinin hem iş, hem de aile hayatlarına ne gibi zorluklar kattığı göz önüne alınarak tartışılmıştır. Makale için hayata geçirilen araştırmada İstanbul ilinde yaşayan 105 çalı̧an anneye ulaşılmış ve 82'sinden anlaml veri elde edilmiştir. Yüz yüze gerçekleştirilen bu kantitatif araştırmada çalışan annelerin hayat standartları, kurumun onu destekleme kapasitesi ve iş-aile hayatı çatışmasıyla örgütsel bağhllık ilişkisi araştırılmıştır. Bu araştırmanın sonucunda çalışan anneler açısından kurumsal bağhllık ile yaşam tatmini, hayatlarında üstlendikleri kimlikler (iş ve aile vb.), iş tatmini ve örgütsel destek arasında anlamlı bir ilişki olduğu, kurumsal bağlllık ile iş-aile hayatı çatışması arasında ise anlamlı negatif bir ilişki olduğu bulgulanmıştır.

\footnotetext{
${ }^{1}$ Asst. Prof., Altınbaş University, arzu.cakar@altinbas.edu.tr,

2 elif.dogan@altinbas.edu.tr,
} 


\section{INTRODUCTION}

Throughout history, working women have been stigmatized. This study analyzed the responsibilities of women, especially working women who are mothers, and looks at how their status affects them in business life, in their private lives, as well as in which way it affects the organization that employs them in the greater context of social environment issues. Additionally, it evaluates how family circles and overall support structure affect their organizational commitment. Within the scope of the research, organization and organizational commitment concepts were considered. Factors influencing organizational commitment were investigated, focusing on the problems they encounter within and outside the organization and how they affect their organizational commitment.

This article has two bases: The first is the organizational commitment effect on working mothers. The second principle is to evaluate the organizational commitment of working women and mothers. The hypotheses determined to achieve these two objectives will be examined.

\subsection{Women in Working Life}

In history, women have been involved in various ways in working life since the beginning of humanity. Still, women's participation in working life in working for wages only began after the industrial revolution towards the end of the 18th century (Hobsbawm, 1968).

Even if working women's regulations begin for the first time in England, the rules and laws are limiting until the onset of both World Wars, which created a necessity in the economic field far more significant than any historical stigma thus far. Also, with the Turkish Republic's proclamation, legislative changes empowering women allowed them to take part actively in business (Balay, 2001).

\subsection{Working Women Issues}

Different reasons prevent women from participating in working life, such as child-care requirements, education, increased difficulty finding a job, and unsuitable working conditions. On the other hand, one of the reasons that forced women to enter working life is the difficulty of living with one family income. the desire to work due 
to the increase in women's education level, the tendency to benefit from the female workforce in production.

Legal regulations are made for working women today, but women still face many problems. The most crucial issue is working hours and unfair remuneration. Although women demonstrate all their performances in their business life, they cannot increase their work. On the other hand, women who are single due to extreme working conditions postpone their marriage, while married women are continually shifting their child plans that make sense of the family because of working conditions and economic concerns. Working women also struggle with their children, spouses, elderly, sick family members, and their homes outside of working hours (Gideon, 2014).

\subsection{Searching for Solutions to the Problems of Working Women}

Some reasons prevent women from entering working life who need the benefits stemming from additional income to prosper. (Eser, 1990) Reasons such as the problem of child-care, the difficulty of finding a suitable job in terms of education, profession, and status, inconvenience of working conditions, the negativity of the idea of working women in the social structure. Economic and social reasons come first among the reasons that require women to work. It is the only source of income in the family, and the difficulty of living with a person's income, the increase in the educational level of women in recent years. The desire to work, the desire to gain economic freedom, the changes in the traditional family structure, the tendency to benefit from the female workforce in production and professional satisfaction are the other reasons (Hablemitoğlu, 1998).

For solving the problems that women are faced, working hours should be stretched or reduced, and milk leaves permitted, etc. permits should be increased, legal regulations should be made on issues such as early retirement (Öztürk, 2017). While working, arrangements should be made where they can be more productive and peaceful. Women's working conditions should be secured, and job opportunities should be created under more favourable conditions. Equal and equitable treatment should be provided regardless of gender, and community sensitivity should be ensured (Castilla, 2008). 
Education is a significant factor in improving women's working conditions. Early marriages cause women not to finish their education, and state and local governments should help women in support (Kavak et al., 2018). If there are families of working women, both society and spouses should take responsibility, and public services should be increased in the care of children, patients, elderly and disabled people (Castilla, 2008).

\subsubsection{Difficulties Faced by Working Mothers}

An important question is who the person will be that takes care of the children during the hours when the mother is at work. Generally, grandmother and grandmother support is needed, and the child is raised with different discipline methods. The mother, who missed her mother at the time of return from work, the child in need of any kind of attention from her, and many working mothers who need to be done with the house have a hard time. Household responsibilities may coincide with workplace responsibilities and the role of motherhood. For example, child emergencies (illness, etc.) disrupt the work. Working mothers have a feeling of guilt with the thought that they cannot spend enough time with their children, and in some discourses coming from the environment (e.g., raising your child.) increases the feeling of guilt (Yavuzer, 1996).

\section{ORGANIZATIONAL COMMITMENT CONCEPT}

The organization's commitment to the organization that directs its employees to stay in the organization can be defined as organizational commitment. The concept of organizational commitment does not have a standard definition, like other management concepts. This is because researchers working in different disciplines (such as psychology and sociology) interpret the issue from different perspectives (Karagüzel, 2012). Some of the definitions are as follows; Celep (2000) defines an individual's behaviour towards these goals and values beyond the formal and normative expectations that an organization expects from the individual.

When organizational commitment is emphasized after the 1970s is examined, many different definitions emerge (Oliver, 1990). Some of the definitions are as follows: Morrow defines organizational commitment with the concepts of loyalty, 
identification with the organization, and adopting the objectives of the Organization (Morrow, 1983). Within this framework, organizational behaviour researchers define employees as a process in which they identify with the organization's goals and values and maintain their membership in the Organization (Mowday et al., 1979).

There are three leading indicators of organizational commitment:

- Adhering to organizational goals and values

- Spending effort to achieve the organization's goals

- Having a strong desire to remain and continue as a member of the organization.

Based on these, Meyer and Allen have determined organizational commitment in three dimensions (Mowday et al., 1979). They defined emotional commitment as the desire of the employees to remain in the business emotionally. Continuity loyalty is defined as the costs of employees leaving the business, that is, considering negativities and continuing the business as a necessity, and Normative dependency is expressed as the employees feel connected to the organization with a moral sense of duty and believe that they should not leave the business (Meyer and Allen, 1997).

\subsection{Results of Organizational Commitment}

According to the type of commitment, the results of commitment to the organization change either positively or negatively. The objectives of the organization determine the employee's commitment to the organization. When the purpose of an organization acceptable by the employee is mentioned, it is seen that the commitment is high. In a contrary situation, one can talk about a low commitment and an organization that can be disbanded (Vurdu, 2017).

\subsubsection{High Organizational Commitment}

In cases where the employee has a high commitment to the organization, it becomes dominant in organizational commitment. The satisfaction of the employee from work done, the working environment, and his colleagues are high. Studies on this issue show that employees with high commitment are more devoted to the organization's goals and work longer in their organizations (Türkmen, 2016). 


\subsubsection{Moderate Organizational Commitment}

Employee working time in the organization is high; however, commitment in the organization is not complete. The objectives and values of the organization are partially accepted. On the other hand, while trying to give the organization's expectations, it maintains its internalization and individual characteristics (Ak1nc1 and Coşkun, 2007).

\subsubsection{Low Organizational Commitment}

A person does not have strong ties to the organization and does not see himself as part of the organization. Employees with a low level of commitment will seek different job opportunities. Thus, he will use his resources more actively. Absenteeism, low motivation, being late for work, lack of willingness to work in the organization, low efficiency, unfaithfulness to the organization, poor performance, changing the home address. It can be shown as causing low-level commitment (Budak \& Surgevil, 2005).

\section{RESEARCH METHODOLOGY}

The primary purpose of this quantitative research conducted with 82 working mothers in private and public sectors with more than 200 employees is to understand their organizational commitment by observing their relationship with several independent variables. The main reason for focusing on the sample of working mothers in companies more than 200 employees is to have the probability of observing a certain level of organizational commitment. The data used in the study was collected and analyzed in 2019. Since the data are collected before 2020, an ethical committee decision is not required for this research.

The online research was conducted in Istanbul in order to get genuine answers from working mothers with a five-point Likert type scale that the questions were in

the scale as (1) Strongly Disagree, (2) Disagree, (3) Undecided, (4) Agree, (5) Strongly Agree. In order to evaluate the relationship between organizational commitment and other factors, there were five different scales used in this study:

The life satisfaction scale developed by Pavot and Diener was used as the life satisfaction scale (Pavot \& Diener, 1993).). Forty questions in the first part of the survey 
were applied to measure family and work satisfaction. Also, the organizational commitment developed by Meyer and Allen to measure organizational commitment from the questions included; affective commitment, continuance commitment, normative commitment, including three dimensions measure 18-point Likert-type scale is used, (Meyer \& Allen, 1984 \& 1997) and the Turkish version developed by Yalçın and İplik (Yalçın \& İplik, 2005).

Work-family conflict was measured with a work-family conflict scale of 18 expressions. In the questionnaire applied in the scale, nine questions in the first part were used for the family, and nine questions in the second part were used for the job conflicts. The scale is a 5-point Likert scale. Moreover, it was developed by Netenmeyer et al. (Netenmeyer et al., 1996) to measure family-work conflict levels. The scale was translated into Turkish by Efeoğlu (Efeoğlu, 2006) and applied in the pharmaceutical sector for the first time.

The Maslach burnout scale was measured in section 4 (a) of the questionnaire. Twenty-two questions were used (Maslach C. \& Jackson S. 1981). Turkish adaptation, and validity and reliability study conducted by Canan Ergin (Ergin., 1999). The "Maslach Burnout Inventory" consists of 22 items.

The organizational support scale consists of 9 questions. Perceived Organizational Support Scale (POS) was developed by Eisenberger et al. (1986) to determine the level of organizational support perceived by employees, and the "Perceived Organizational Support Scale" was abbreviated as ten items by Stassen and Ursel (Stassen \& Ursel, 2009). The Turkish validity reliability of the Perceived Organizational Support Scale was performed by Akkoç et al. (Akkoç et al., 2012).

The social support scale consists of 12 items in the 5th section of the questionnaire. The multidimensional perceived social support scale (MSPSS) contains three groups. These are family, (3-4-8-11) friends (6-7-9-12), and a special person. (1-25-10) The scale was translated into Turkish by Doğan Eker and developed by Haluk Arkar (Eker \& Arkar 1995). The high score obtained in this study indicates that perceived social support is high. 
One hundred five working mothers commenced the survey. However, 82 of them fully completed. Sample tolerance is $10 \%$, which could be regarded as a limitation for this study. On the other hand, even though there is not a firm reference regarding the exact percentage but the total number of working mothers in large companies is relatively low in Turkey. Therefore, the sample size in this research can be regarded as strong enough to drive meaningful outcomes.

The demographic breakdowns of 82 mothers working mothers are as follows: Of the 82 mothers surveyed, $32.9 \%$ were between $18-29$ years old, $47.6 \%$ were between $30-40$ years old, $19.5 \%$ were over 40 years old; $61.0 \%$ is married. In the assessment of the number of children, $29.2 \%$ had no children, $35.4 \%$ had $1,30.5 \%$ had $2,4.9 \%$ had three children.

Table 1. Distribution of the Sociodemographic Characteristics of the Sample

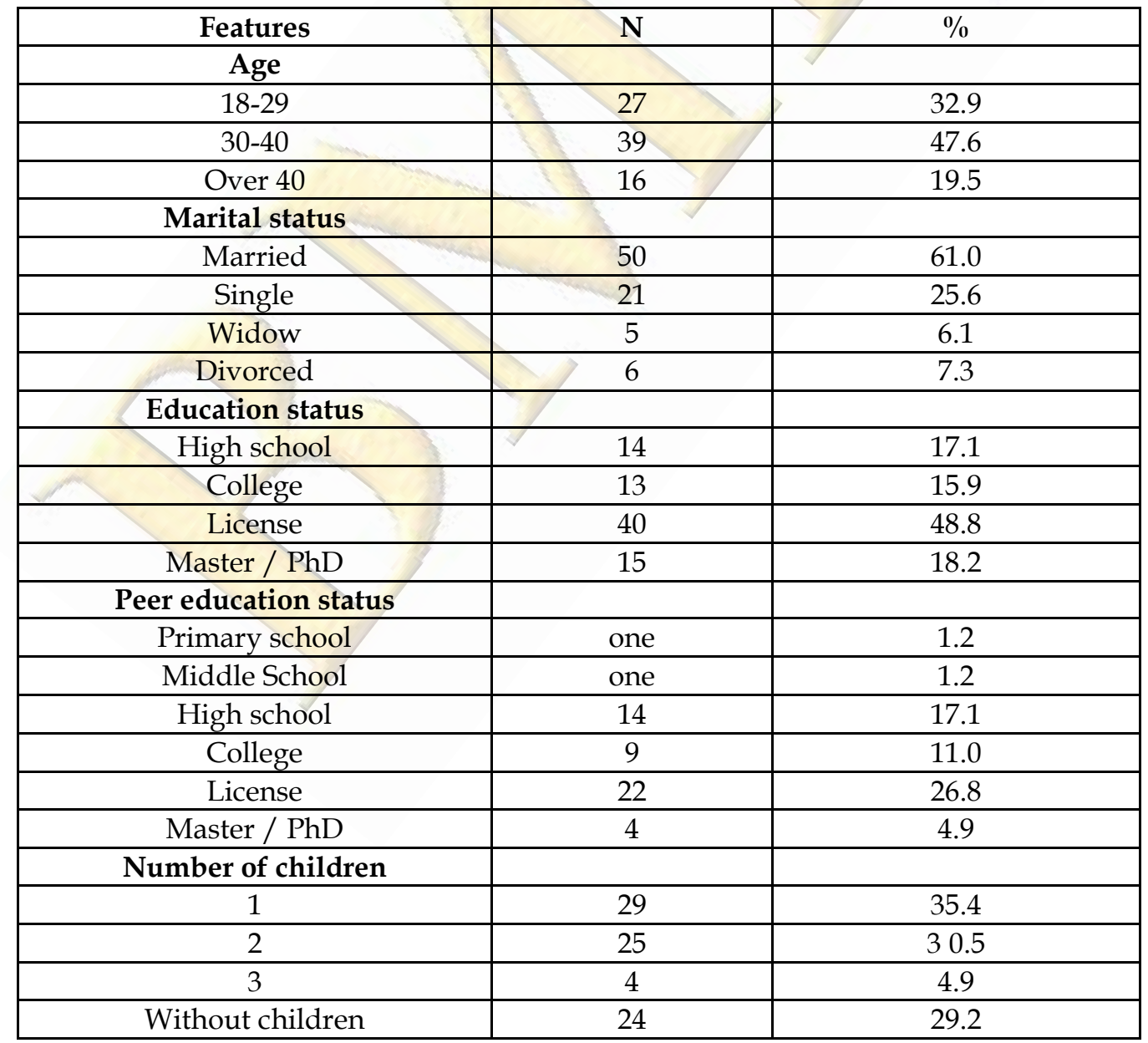


In order to understand the organizational commitment of working mothers thoroughly, the research data has been evaluated through the following Hypothesis.

Hypothesis 1: There is a significant relationship between organizational commitment and life satisfaction.

Hypothesis 2: There is a significant relationship between organizational commitment and roles in life (business life or family life).

Hypothesis 3: There is a significant relationship between organizational commitment and work life, job satisfaction, organizational support.

Hypothesis 4: There is a significant negative relationship between work-family conflict and organizational commitment.

The dependent variable is an organizational commitment; independent variables are work-family conflict/social environment/organizational support/demographic features-work life roles. SPSS 21.0 was utilized in data analysis, and besides descriptive statistical techniques, the relationship (with Pearson correlation) and the differences in the responses (with t-test and variance analysis) were investigated.

\section{RESEARCH FINDINGS}

The results of the research are tried to be explained with the six hypotheses created. Research results with established hypotheses affect organizational commitment in what direction they show the other.

Hypothesis 1: There is a significant relationship between organizational commitment and life satisfaction. 
Table 2. Evaluation of the Relationship Between the Significance of the Job Role in the Lives of the Mothers Participating in the Study and Other Scale Scores

\begin{tabular}{|c|c|c|}
\hline Subtitle & Statistics & Job role clarity \\
\hline \multirow{3}{*}{ Family role clarity } & $\begin{array}{l}\text { The correlation coefficient } \\
(\mathrm{r})\end{array}$ & 204 \\
\hline & $\mathrm{p}$ &, 090 \\
\hline & $\mathrm{N}$ & 70 \\
\hline \multirow{3}{*}{$\begin{array}{l}\text { The effect of workplace responsibilities } \\
\text { on family life }\end{array}$} & $\begin{array}{l}\text { The correlation coefficient } \\
\text { (r) }\end{array}$ & 210 \\
\hline & $\mathrm{p}$ &, 068 \\
\hline & $\mathrm{N}$ & 76 \\
\hline \multirow{3}{*}{$\begin{array}{l}\text { The effect of family responsibilities on } \\
\text { business life }\end{array}$} & $\begin{array}{l}\text { The correlation coefficient } \\
(\mathrm{r})\end{array}$ & $241^{*}$ \\
\hline & $\mathrm{p}$ & 037 \\
\hline & $\mathrm{N}$ & 75 \\
\hline \multirow{3}{*}{ Organizational support } & $\begin{array}{l}\text { The correlation coefficient } \\
(\mathrm{r})\end{array}$ & $259^{*}$ \\
\hline & $\mathrm{p}$ &, 026 \\
\hline & $\mathrm{N}$ & 74 \\
\hline \multirow{3}{*}{ Social support } & $\begin{array}{l}\text { The correlation coefficient } \\
\text { (r) }\end{array}$ &, 103 \\
\hline & $\mathrm{p}$ & 377 \\
\hline & $\mathrm{N}$ & 76 \\
\hline \multirow{3}{*}{ Emotional exhaustion } & $\begin{array}{l}\text { The correlation coefficient } \\
\text { (r) }\end{array}$ & -120 \\
\hline & $\mathrm{p}$ & 300 \\
\hline & $\mathrm{N}$ & 76 \\
\hline \multirow{3}{*}{ Despite correlation } & $\begin{array}{l}\text { The correlation coefficient } \\
\text { (r) }\end{array}$ &, 034 \\
\hline & $\mathrm{p}$ & 767 \\
\hline & $\mathrm{N}$ & 77 \\
\hline \multirow{3}{*}{ Personal success } & $\begin{array}{l}\text { The correlation coefficient } \\
(\mathrm{r})\end{array}$ &, 083 \\
\hline & $\mathrm{p}$ & 474 \\
\hline & $\mathrm{N}$ & 76 \\
\hline
\end{tabular}

According to the Pearson Correlation analysis conducted to evaluate the relationship between the work roles in the mothers' life satisfaction assessed in the study, it was determined that the role of the work roles in the individuals' lives correlated positively with the organizational support. It was determined that the effect of family responsibilities of individuals on business life $(r=0.2241, p=0.037)$ and the organizational support they felt $(\mathrm{r}=0.259, \mathrm{p}=0.025)$ affected the role of work in their 
lives. It was observed that there was no correlation between the other scale scores evaluated in the study and the role of work role in mothers' lives ( $p>0.05)$.

Hypothesis 1 is supported.

Hypothesis 2: There is a significant relationship between organizational commitment and roles in life (business life or family life).

Table 3. Distribution of the Occupational Characteristics of the Mothers and Their Spouses $(\mathrm{N}=82)$

\begin{tabular}{|c|c|c|}
\hline Features & $\mathbf{N}$ & $\%$ \\
\hline \multicolumn{3}{|l|}{ Industry in which it operates } \\
\hline Special & 57 & 69.5 \\
\hline Public & 19 & 23.2 \\
\hline Own business & 6 & 7.3 \\
\hline \multicolumn{3}{|c|}{ The sector in which the spouse works } \\
\hline Special & 35 & 42.7 \\
\hline Public & 18 & 22.0 \\
\hline Own business & 29 & 35.4 \\
\hline \multicolumn{3}{|l|}{ Weekly working hours } \\
\hline Less than 40 hours & $\begin{array}{l}12 \\
2 \quad 10\end{array}$ & 14.7 \\
\hline 40 hours & 39 & 47.6 \\
\hline 45 hours & 22 & 26.8 \\
\hline More than 46 hours & 9 & 10.9 \\
\hline \multicolumn{3}{|l|}{ Days of weekly leave } \\
\hline Less than two days & 14 & 17.2 \\
\hline Two days & 63 & 76.8 \\
\hline More than two days & 2nd & 2.4 \\
\hline \multicolumn{3}{|l|}{ Working year } \\
\hline $4 \geq$ & 30 & 37.0 \\
\hline 5-14 years & 26 & 31.7 \\
\hline $15 \leq$ & 25 & 31.3 \\
\hline \multicolumn{3}{|l|}{ Monthly income } \\
\hline $3500 \geq$ & 30 & 34.7 \\
\hline $3501-5500$ & 23 & 30.7 \\
\hline $5501 \leq$ & 26 & 34.7 \\
\hline
\end{tabular}


Hypothesis 2 is supported.

Hypothesis 3: There is a significant relationship between organizational commitment and work life, job satisfaction, organizational support.

Table 4. Distribution of Organizational Support and Social Support Scores of the Mothers Participating in the Study $(\mathrm{N}=82)$

\begin{tabular}{|c|c|c|c|c|c|}
\hline Sub Dimensions & $\mathbf{N}$ & Average & Standard deviation & $\begin{array}{c}\text { The } \\
\text { smallest }\end{array}$ & The biggest \\
\hline Organizational support & 82 & 3.32 & 0.63 & 1.78 & 4.78 \\
\hline Social support & 82 & 4.18 & 0.76 & 1.00 & 5.00 \\
\hline
\end{tabular}

The scores of participants from the scales directed about organizational and social support are shown in Table 4.

Hypothesis 3 is supported.

Hypothesis 4: There is a significant negative relationship between work-family conflict and organizational commitment.

Table 5. Distribution of the Mothers Participating in the Study Prioritizing Work and Family Life $(\mathrm{N}=82)$

\begin{tabular}{|l|l|l|l|l|l|}
\hline Sub Dimensions & $\mathbf{N}$ & Average & $\begin{array}{l}\text { Standard } \\
\text { deviation }\end{array}$ & $\begin{array}{l}\text { The } \\
\text { smallest }\end{array}$ & $\begin{array}{l}\text { The } \\
\text { biggest }\end{array}$ \\
\hline $\begin{array}{l}\text { The effect of workplace } \\
\text { responsibilities on family life }\end{array}$ & 82 & 2.67 & 0.72 & 1.00 & 5.00 \\
\hline $\begin{array}{l}\text { The effect of family responsibilities } \\
\text { on business life }\end{array}$ & 82 & 2.40 & 0.65 & 1.00 & 4.56 \\
\hline
\end{tabular}

The distribution of the average score of the participants who participated in the study from 9 questions about the problems they may encounter in family life while trying to fulfil their responsibilities in the workplace and nine problems related to the problems that they may encounter in the business life while trying to fulfil their family responsibilities are shown in Table 5.

Hypothesis 4 is not supported. 


\section{RESULTS}

This study aims to determine whether there is a relationship between working mothers' demographic characteristics, family and work life, work-family roles, workfamily role conflicts, social environment, social and organizational support, and organizational commitment.

This study shows that demographic factors are influential in organizational commitment. It shows that the age, education level, gender, marital status of the employee, and the length of service he/she worked play a significant role in organizational commitment. There are positive relationships between employees' age, education, marital status, number of children, length of service, and attachment to their profession or organizations. Organizational commitment of employees in the 1829 age range is higher than other age groups.

There are differences between the service period and the employee's commitment to the organization in the research. It is observed that employees with a total working period of 6-10 years are more loyal to their company/institutions than other service periods. It can be said that employees have been working for 6-10 years by adopting the values and goals of their organizations more during this period.

Although there is no significant difference in their marital commitment levels, married women have a high family role. It has been found that single women have higher organizational commitment. There was no difference between the number of children and organizational commitment. It has been determined that there is a negative relationship between organizational commitment and education level, especially when the "educational status" examined within the demographic structure is taken into consideration. In other words, the personal success of employees who are high school graduates has been determined to be higher than those of undergraduate graduates.

The next generation in Turkey is thought to be more educated, more intellectual, more active, more creative, and productive. Workplaces have to consider this "new knowledge worker" model. In this study, the organizational commitment of working women and mothers and their effects on life satisfaction through work-family conflict 
were examined, and the hypotheses prepared within the scope of the model were confirmed. The fact that the employees love their profession and endure various sacrifices for their profession also positively affects their life satisfaction.

It is seen that work-family roles have a higher effect on organizational commitment. Organizational commitment is one of the critical commitment types that affect life satisfaction.

The decrease in organizational commitment through work-family conflict is a negative relationship. As it can be understood, organizational commitment decreases as work-family conflict increases. The fact that this study's participants do not experience work-family conflict at severe levels will increase organizational commitment.

In summary, the more work-family conflict, the less organizational commitment of the employees. In order to increase the life satisfaction of women, it is necessary to reduce work-family conflicts. It was understood with this research that one of the most important factors that provide life satisfaction, family, and individual being in harmony and being less in conflict is to increase the professional, career, and organizational commitment of individuals.

There are positive relationships between work life, job satisfaction, organizational support, and social life of the individual and work life. Favourable or unfavourable situations in the individual's work-life reflect positively and negatively on his social life. There are positive relations between business life and social life. The commitment of the individual in the organization creates an increasing effect on life satisfaction. Therefore, there is a spread from one to the other.

As a result, we can mention many factors affecting the organizational commitment of working mothers.

These are;

- Demographic characteristics of working mothers. Their age, marital status, years of service, etc., each interacts with working mothers' organizational commitment. 
- Organizational commitment is higher among those in the 18-29 age range. Organizational commitment dimension of single employees is higher than married ones.

- Organizational commitment of women with high social support and positive family life also increases at the same rate. Today, the support of working women in business and family life increases their organizational commitment.

- The problems women experience in the family can negatively affect their business life and organizational commitment.

- The organizational commitment of an employee with organizational support increases. Employees with a high organizational commitment level do not think of leaving as they make extra effort to achieve organizational goals.

- Organizational commitment dimensions of employees with low burnout levels increase.

\section{FUTURE RESEARCH RECOMMENDATIONS AND LIMITATIONS}

According to the research results, it is necessary to listen to the problems and suggestions of mothers who work in the public, private sectors for taking severe measures in order to increase their organizational commitment. Similar research can be conducted for working mothers who are entrepreneurs. There can be similar problems to be foreseen and prevented. On the other hand, entrepreneur mothers can face problems specifically for running their businesses. Therefore, it can be beneficial to shed light on the possible problems and solutions for entrepreneur mothers. Focusing on the problems regarding organizational commitments from the entrepreneurship perspective can have rich outcomes both for academicians and professionals.

Through the light of this study, there are steps to be taken for policymakers, such as improving working conditions, increasing women's education level, providing daycare and child benefits for working mothers. Necessary regulations should be made in the legislation in line with these policies. 
There were certain limitations to this study. First of all, from the research perspective, there are two main improvement areas. Firstly, the sample size could be increased to 384 in order to decrease the sample tolerance to $5 \%$ with a $95 \%$ confidence interval. Even though working mothers shy out to participate in such a study with several intimate questions, it is still necessary to increase the strength of the findings. Secondly, a qualitative phase could be utilized, followed by quantitative research in order to understand working mothers by retrieving deeper insights. 


\section{REFERENCES}

Akıncı VZB \& Coşkun. G. (2007). Organizational Culture: Communication. Leadership. Motivation. Loyalty. Evaluation in terms of performance. Nobel Publishing. Ankara.

Akkoç, S. (2012). An empirical comparison of conventional techniques, neural networks and the three stage hybrid Adaptive Neuro Fuzzy Inference System (ANFIS) model for credit scoring analysis: The case of Turkish credit card data. European Journal of Operational Research, 222(1), 168-178.

Armstrong-Stassen, M., \& Ursel, N. D. (2009). Perceived organizational support, career satisfaction, and the retention of older workers. Journal of occupational and organizational psychology, 82(1), 201-220.

Balay, R. (2001), “Yönetici ve Öğretmenlerde Örgütsel Bağlllık”, Nobel Yayın Dağıtım, Ankara.

Budak, G.\& Sürgevil, O. (2005). An application on burnout and the analysis of organizational factors affecting burnout on academic staff. Journal of D.E.U.I.B.F., 20 (2), 95-108.

Castilla, E. J. (2008). Gender, race, and meritocracy in organizational careers. American Journal of Sociology, 113(6), 1479-1526.

Celep, C. (2000). Organizational Devotion and Teachers in Education. Ankara: Anı Publishing.

Efeoğlu, İ. E. (2006). İş-Aile Yaşam Çatışmasının İş Stresi, İş Doyumu ve Örgütsel Bağl1lık Üzerindeki Etkileri: İlaç Sektöründe Bir Çalışma. (Doktora tezi). Çukurova Üniversitesi Sosyal Bilimler Enstitüsü.

Eisenberger, R., Huntington, R., Hutchison, S., \& Sowa, D. (1986). Perceived organizational support. Journal of Applied psychology, 71(3), 500.

Eker, D., \& Arkar, H. (1995). Perceived social support: psychometric properties of the MSPSS in normal and pathological groups in a developing country. Social psychiatry and psychiatric epidemiology, 30(3), 121-126.

Ergin, C. (1992). Nadir Kitapevi İnsan Kaynakları Yönetimi, İstanbul

Eser, Ş. (1990). The Effects of Women's Work on the Family, I. Family Council Papers Presentation Series No: 3, Ankara

Gideon, J. (2014). Gender, globalization, and health in a Latin American context. New York: Palgrave Macmillan. 
Hablemitoğlu,, Ş., (1998). Part-Time Working Opportunities for Women in Balancing Work and Family System, Journal of Productivity, P.4.

Hobsbawm, E.C. (1968), Industry and Empire, New York: Pantheon Books.

Karagüzel, E.S. (2012). Örgüt Sağlı̆̆ının Örgütsel Bağlılığa Etkisinin Ǵncelenmesi (Bir Devlet Üniversitesi Örneği). Yayımlanmamış Yüksek Lisans Tezi, Sakarya Üniversitesi Sosyal Bilimler Enstitüsü, Sakarya

Kavak, F., Aktürk, Ü., Özdemir, A., \& Gültekin, A. (2018). The relationship between domestic violence against women and suicide risk. Archives of psychiatric nursing, 32(4), 574-579.

Maslach, C., Jackson, S. E., Leiter, M. P., Schaufeli, W. B., \& Schwab, R. L. (1986). Maslach burnout inventory (Vol. 21, pp. 3463-3464). Palo Alto, CA: Consulting psychologists press.

Meyer, J.P. and Allen, N.J. (1984). Testing the Side-Bet Theory of Organizational Commitment:Some Methodological Considerations, Journal of Applied Psychology, 64/3,

Meyer, J.P. \&. NJ ALLEN; (1997), Commitment in the Workplace, Sage, Thousand Oaks. MILLER, DC; (1991), Handbook of Research Design and Social Measurement, 5.th ed., CA: Sage Publications.

Morrow, P.C. (1983). Concept Redundancy in Organizational Research: The Case

Mowday, RT, RM Steers \& LWPorter (1979) 'The Measurement Of Organizational Commitment, Journal of Vocational Behavior,

Netemeyer, R. G., Boles, J. S., \& McMurrian, R. (1996). Development and validation of work-family conflict and family-work conflict scales. Journal of applied psychology, 81(4), 400.

Oliver, N. (1990) "Rewards, Investments, Alternatives and Organizational Commitment: Empirical Evidence and Theoretical Development," Journal of Occupational Psychology,

Pavot, W., \& Diener, E. (1993). The affective and cognitive context of self-reported measures of subjective well-being. Social Indicators Research, 28(1), 1-20.

Türkmen. F. (2016). Ortaokul Yöneticilerinin Hizmetkâr Liderlik Davranışlarının Öğretmenlerin Örgütsel Bağlılıkları Üzerindeki Etkisi (Sinop İli Örneği). (Yüksek Lisans Tezi). Ondokuz Mayıs Üniversitesi Eğitim Bilimleri Enstitüsü

Vurdu, U. (2017). The Relationship Between Professional Burnout Status and Organizational Commitment of Teachers Working in Official Schools. (Master's Thesis). Yeditepe University Educational Sciences Institute Educational Administration and Supervision Department. Istanbul.

Yalçın, A. \& Iplik F.N. (2005), Bes, Yıldızlı Otellerde C,alışanların Demografik Ozellikleri Ile Orguitsel Baglılıkları Arasındaki Iliş̧kiyi Belirlemeye Yönelik Bir Araștırma: Adana Ili Orneğı, C,ukurova Universitesi Sosyal Bilimler Enstitüsü Dergisi, Cilt:4, Say1:1, ss. 395-412.

Yavuzer, H. (1996). Parent and child. Istanbul: Remzi Bookstore. 